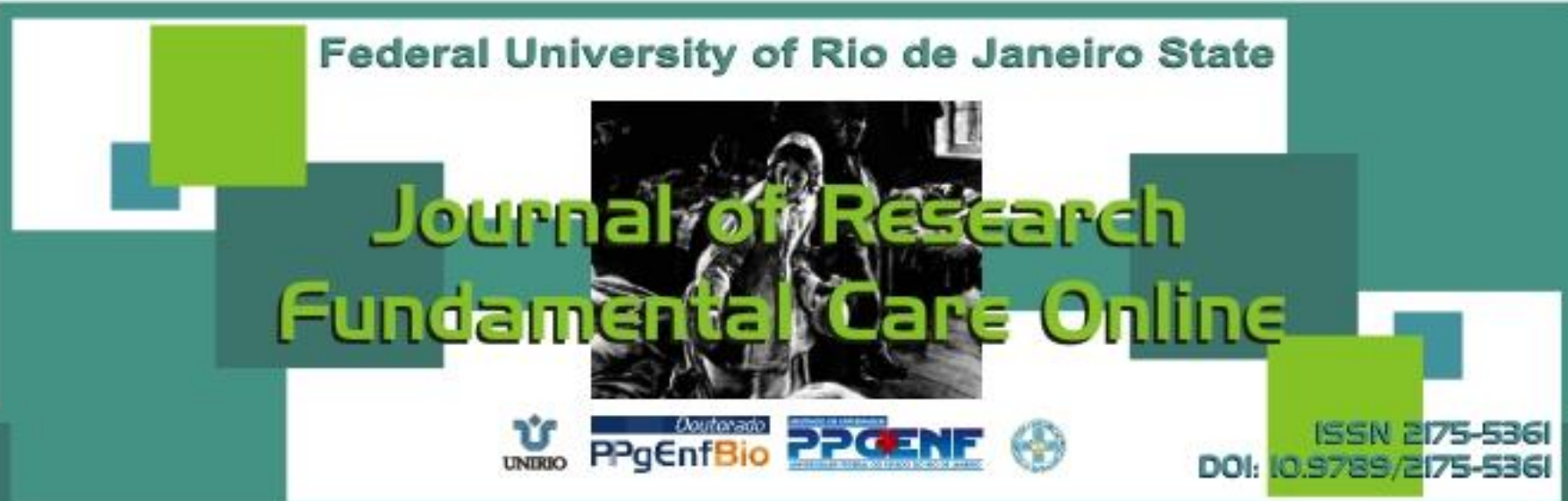

INTEGRATIVE REVIEW OF THE LITERATURE

\title{
Percepção de idosos sobre alzheimer
}

Perception of elderly on alzheimer

La percepción de las personas mayores sobre alzheimer

Ronaldo Bezerra de Queiroz ${ }^{1}$, Sônia Mara Gusmão Costa ${ }^{2}$, Juliana Almeida Marques Lubenow ${ }^{3}$

Sandra Aparecida de Almeida ${ }^{4}$, Maria Adelaide Silva Paredes Moreira ${ }^{5}$, Antonia Oliveira Silva ${ }^{6}$

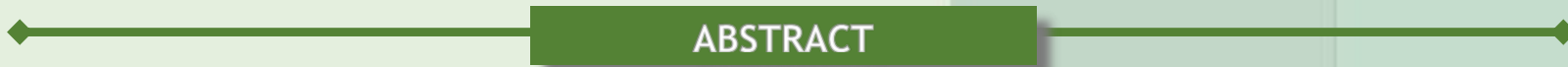

Objective: it is an integrative literature review, in order to verify the knowledge produced by researchers about the perception of older people on Alzheimer's disease (AD). Method: the literature review was conducted in the Virtual Health Library (BVS BRAZIL), MEDLINE and in the Capes Journal Portal databases. Results: the final sample consisted of nine scientific articles selected by previously established inclusion criteria. It was noticed the little amount of scientific articles published on Alzheimer's disease with qualitative methodology using the Theory of Social Representations (SR). Conclusion: there was the need for research to investigate the behavior of elderly patients in face of Alzheimer's disease having the theory of SR as theoretical support so that in the near future benefits with scientific basis are accumulated, creating opportunities for interventions such as health policies, with the main purpose to improve the quality of life for seniors. Descriptors: Perception, Elderly, Alzheimer's disease.

RESUMO

Objetivo: verificar o conhecimento produzido pelos pesquisadores a respeito da percepção dos idosos sobre a doença de Alzheimer (DA). Método: revisão integrativa da literatura com levantamento bibliográfico realizado na Biblioteca Virtual em Saúde (BVS), MEDLINE e nos bancos de dados do Portal de Periódicos Capes. Resultados: a amostra final foi constituída por nove artigos científicos, selecionados pelos critérios de inclusão previamente estabelecidos. Observou-se a incipiência de artigos científicos publicados sobre a Doença de Alzheimer com metodologia qualitativa que utilize a Teoria das Representações Sociais (RS). Conclusão: verificou-se a necessidade de pesquisas para investigar o comportamento de idosos em face à doença de Alzheimer tendo como aporte teórico a teoria das RS para que em um futuro próximo se acumule subsídios com base científica criando possibilidades de haver promoções de intervenções como políticas de saúde, com finalidade precípua de melhorar a qualidade de vida destes. Descritores: Percepção, Idoso, Doença de alzheimer.

RESUMEN

Objetivo: verificar el conocimiento producido por los investigadores acerca de la percepción de ancianos acerca de la enfermedad de Alzheimer (EA). Método: la revisión de la literatura se realizó en la BVS, bases de datos MEDLINE y Portal de Periódicos Capes. Resultados: la muestra final estuvo compuesta por nueve artículos científicos seleccionados por criterios de inclusión previamente establecidos. Se observó la escasez de articulos científicos publicados sobre la enfermedad de Alzheimer con metodología cualitativa utilizando la Teoría de las Representaciones Sociales (RS). Conclusión: hubo la necesidad de investigación con el fin de investigar el comportamiento de los ancianos frente la enfermedad de Alzheimer y como soporte teórico la teoría de la RS para que en un futuro próximo para acumular conocimientos con base científica creando oportunidades para intervenciones y políticas de salud, con el objetivo de mejorar la calidad de vida de estos ancianos. Descriptores: Percepción, Ancianos, Enfermedad de alzheimer.

1Neurologist HULW-UFPB. PhD Student in Nursing and Health. PPGENF - UFPB. E-mail: qronaldo@hotmail.com 2 Physical therapist, PhD Student in Nursing and Health. PPGENF - UFPB. E-mail: sonia.gusmaocosta@yahoo.com.br 3 Nurse, PhD Student in Nursing and Health. PPGENF - UFPB. E-mail:julianalmeidamarques@hotmail.com 4 PhD in Nursing. Professor of the Postgraduate Program in Nursing at UFPB. E-mail: sandraalmeida124@gmail.com 5 Physical therapist, PhD. Professor of the Postgraduate Program in Nursing at UFPB. E-mail: jpadelaide@hotmail.com 6 Nurse, PhD in Nursing. CNPq Researcher. Professor of the Postgraduate Program in Nursing at UFPB. E-mail:alfaleda@hotmail.combr 


\section{INTRODUCTION}

$\mathrm{n}$ the care practice, it is seen the strong concern of healthy elderly who seek evaluation due to their memory loss and how this may be interfering with their quality of life. There is an inner struggle of humans to accept aging and involution as normal and inevitable stages of life, probably due to the human desire for life youth and immortality.

Research in the field of aging has created basis for valuation of the elderly and of the quality of life of individuals who have the opportunity to grow old. This has been happening due to the scenery of changes with the development of technology and medicine, enabling the increasing number of elderly in the world, and as a result the increase in life expectancy.

It is necessary to understand this term and decide its meaning for this age group to develop policies, actions and interventions of health care to improve the quality of life of the elderly. Thus, targeting future research, it is consistent to search the literature about the discussions addressing the perception of older people about Alzheimer's disease and even the association of other relevant situations that corroborate to the thought of other actions.

The term active aging was adopted by the World Health Organization (WHO) in the late 1990s with the intention to convey a broader message of what healthy aging is, and to recognize, in addition to health care, other factors affecting how individuals and populations age. The WHO defines quality of life as the perception that the individual has of their position in life within the context of their culture and value system in which they live, in relation to their goals, expectations, standards and concerns. It is a broad concept that incorporates in a complex way the physical health of the person, their psychological state, their level of dependency, their social relationships, their beliefs and their relationship to preeminent features in the environment. ${ }^{1}$

With aging, degenerative diseases arise and, among them, Alzheimer's disease (AD). The Manual of Diagnostic and Statistics of Mental Disorders (2014) defines it as a dementia of gradual onset and continuing cognitive decline, with impairment of memory and other cognitive area, in the absence of other diseases that cause progressive deficits in memory and cognition. ${ }^{2}$ With increasing life expectancy, there is a greater knowledge by healthy elderly on the risk of contracting this disease and thus there is need for further research in this population to recognize and reveal what this has caused in their daily lives, and try to offer, in turn, interventions in practice in the search field as well as in the elaboration of proposals on health policies.

Initiative to prevent is an example of current international efforts aimed at improving the methodology for prevention studies and providing the basis for larger intervention studies 
for most types of dementia, including AD. ${ }^{3-4}$ Early diagnosis of dementia aims to increase the quality of health care and provide many direct benefits for people with dementia and their caregivers. ${ }^{5}$ In contrast, the late diagnosis of dementia leads to missed opportunities of treatment, increasing the burden on patients and caregivers. It is noteworthy that addressing knowledge and attitudes about Alzheimer's disease may contribute for the family in making decisions about the symptoms, diagnosis, treatment and participation in research on dementia. ${ }^{6}$

Among the theoretical options to address knowledge and attitudes of older people and caregivers about AD, there is the Theory of Social Representations, which can be understood as a modality of knowledge, as systems of interpretation of reality organize the individual's relations with the world and guide their conduct and behavior in the social environment. ${ }^{7}$

It is presented, as research problem, how the scientific work of national and international journals indexed in the database Virtual Health Library (BVS BRAZIL), MEDLINE and the Capes Journal Portal on the theme perception of seniors about $A D$, which aims to verify the knowledge produced by researchers in such databases.

\section{METHOD}

It was decided to carry out this study using the integrative review method, since it allows the search, critical evaluation and synthesis of available evidence about the research theme, and its final product is the state of the current art of this knowledge. ${ }^{8}$

The literature review was conducted in March 2015 in the internet, in the Virtual Health Library (BVS BRAZIL), MEDLINE and Capes Journal Portal databases. Starting from the descriptors setting process, it was used the operator "health terminology", where it was identified relevant terms for the studies, such as the descriptors Alzheimer and Perception; Perception and Alzheimer's Disease; Alzheimer and Perception; Alzheimer's Disease and Perception, with the Boolean indicator AND.

After the establishment of the inclusion criteria, complete articles published from 2002 to 2014 were included, whose the main subject is Alzheimer's disease, considering the social representations or only the perception of the elderly, in Portuguese, English and Spanish. Exclusion criteria were dissertations, theses and studies that have not been obtained in full or that did not address the theme.

It was developed and applied a data collection instrument called the Registration Form, which was filled for each article of the final sample, allowing obtaining the following information: (1) Source; (2) Title; (3) Authors; (4) Journal/volume, number, page, year; (5) Considerations. Then, it was conducted the quantitative analysis of the data, which were organized in spreadsheets in Microsoft Office Excel 2007 program. The results were expressed as numerical representations, following the systematic distribution by simple frequency, through absolute and percentage values in table. 
Both the analysis and the synthesis of data extracted from the articles were performed descriptively, allowing observing, counting, describing and classifying the data in order to gather the knowledge produced about the theme explored in the review. ${ }^{9}$

There was no need to submit the research project to the Research Ethics Committee because secondary data of the public domain was used.

\section{RESULTS AND DISCUSSION}

The final sample of this review was made up of nine scientific papers, selected by the previously established inclusion criteria. Of these, one $(11.11 \%)$ was found in the BVS BRAZIL/LILACS database, three (33.33\%) in the Capes Portal and five (55.56\%) in MEDLINE.

Tables 1 and 2 present the specifications of each of the articles.

Table 1. Articles collected in databases on Alzheimer's disease and perception of the elderly.

\begin{tabular}{|c|c|c|c|c|}
\hline SOURCE & TITLE & AUTHORS & $\begin{array}{l}\text { JOURNAL (VOL, } \\
\text { No., PÁGE, } \\
\text { YEAR) }\end{array}$ & CONSIDERATIONS \\
\hline MEDLINE & $\begin{array}{l}\text { Public opinion } \\
\text { about Alzheimer } \\
\text { disease among } \\
\text { blacks, hispanics, } \\
\text { and whites: } \\
\text { results from a } \\
\text { national survey }\end{array}$ & $\begin{array}{l}\text { Connell CM; } \\
\text { Scott Roberts J; } \\
\text { McLaughlin SJ. }\end{array}$ & $\begin{array}{l}\text { Alzheimer Dis } \\
\text { Assoc Disord; } \\
21(3): 232-40 \\
2007 \text { Jul-Sep }\end{array}$ & $\begin{array}{l}\text { Assessed racial } \\
\text { differences in } \\
\text { knowledge and } \\
\text { attitudes towards } \\
\text { AD in adults over } \\
35 \text { years old by } \\
\text { telephone } \\
\text { interview. }\end{array}$ \\
\hline $\begin{array}{l}\text { BVS BRAZIL/ } \\
\text { LILACS }\end{array}$ & $\begin{array}{l}\text { Influences of } \\
\text { sociodemographic } \\
\text { characteristics in } \\
\text { knowledge about } \\
\text { Alzheimer's } \\
\text { disease in the } \\
\text { elderly } \\
\text { population of the } \\
\text { city of Santos } \\
\text { (Portuguese) }\end{array}$ & $\begin{array}{l}\text { Matioli MNPS; } \\
\text { Etzel A; Prats } \\
\text { JAGG; Medeiros } \\
\text { WFO; Monteiro } \\
\text { TR; Soares AM. }\end{array}$ & $\begin{array}{l}\text { Dement. } \\
\text { neuropsychol; } \\
\text { 5(2)Jun. } 2011\end{array}$ & $\begin{array}{l}\text { Assessed the } \\
\text { knowledge about } \\
\text { AD in a literate } \\
\text { population of } \\
\text { elderly, } \\
\text { correlating these } \\
\text { findings with } \\
\text { their } \\
\text { sociodemographic } \\
\text { characteristics. }\end{array}$ \\
\hline CAPES PORTAL & $\begin{array}{l}\text { Alzheimer's } \\
\text { dementia and the } \\
\text { elderly: research } \\
\text { on knowledge, } \\
\text { prevention and } \\
\text { perception } \\
\text { (Portuguese) }\end{array}$ & $\begin{array}{l}\text { Oliveira AA; } \\
\text { Albuquerque } \\
\text { FMD; Fonseca } \\
\text { GA; Almeida } \\
\text { VLV. }\end{array}$ & $\begin{array}{l}\text { Fiep Bulletin On- } \\
\text { line; v. } 82 \\
(2012)\end{array}$ & $\begin{array}{l}\text { Identified and } \\
\text { analyzed the } \\
\text { knowledge, } \\
\text { prevention } \\
\text { measures and } \\
\text { perception of } \\
\text { older people on } \\
\text { AD. }\end{array}$ \\
\hline CAPES PORTAL & $\begin{array}{l}\text { Fear of } \\
\text { Alzheimer's } \\
\text { disease in the } \\
\text { French } \\
\text { population: } \\
\text { impact of age }\end{array}$ & $\begin{array}{l}\text { Cantegreil- } \\
\text { Kallen I; Pin S. }\end{array}$ & $\begin{array}{l}\text { International } \\
\text { Psychogeriatrics, } \\
\text { 2012, Vol.24(1), } \\
\text { pp.108-116 }\end{array}$ & $\begin{array}{l}\text { Investigated in } \\
2008 \text {, by } \\
\text { telephone, the } \\
\text { perception, } \\
\text { knowledge, }\end{array}$ \\
\hline
\end{tabular}




\begin{tabular}{|l|l|l|l|l|}
\hline & $\begin{array}{l}\text { and proximity to } \\
\text { the disease }\end{array}$ & & $\begin{array}{l}\text { opinions and } \\
\text { beliefs about AD } \\
\text { in the French } \\
\text { population. }\end{array}$ \\
\hline MEDLINE & $\begin{array}{l}\text { Cultural diversity } \\
\text { and views on } \\
\text { Alzheimer } \\
\text { disease in older } \\
\text { African } \\
\text { Americans }\end{array}$ & $\begin{array}{l}\text { Rovner BW; } \\
\text { Casten RJ; } \\
\text { Harris LF. }\end{array}$ & $\begin{array}{l}\text { Alzheimer Dis } \\
\text { Assoc Disord; } \\
27(2): 133-7, \\
2013 \text { Apr-Jun }\end{array}$ & $\begin{array}{l}\text { Prevailing } \\
\text { cultural } \\
\text { constructions in } \\
\text { older African } \\
\text { Americans } \\
\text { influence their } \\
\text { perceptions and } \\
\text { knowledge of risk } \\
\text { on AD. }\end{array}$ \\
\hline
\end{tabular}

Table 2. Articles collected in databases on Alzheimer's disease and perception of the elderly.

\begin{tabular}{|c|c|c|c|c|}
\hline SOURCE & TITLE & AUTHORS & $\begin{array}{l}\text { JOURNAL (VOL, } \\
\text { No., PÁGE, } \\
\text { YEAR) }\end{array}$ & CONSIDERATIONS \\
\hline MEDLINE & $\begin{array}{l}\text { Re-examining } \\
\text { ethnic } \\
\text { differences in } \\
\text { concerns, } \\
\text { knowledge, and } \\
\text { beliefs about } \\
\text { Alzheimer's } \\
\text { disease: results } \\
\text { from a national } \\
\text { sample }\end{array}$ & Ayalon L. & $\begin{array}{l}\text { Int J Geriatr } \\
\text { Psychiatry; } \\
\text { 28(12): 1288-95, } \\
\text { 2013 Dec }\end{array}$ & $\begin{array}{l}\text { Assessed } \\
\text { differences in } \\
\text { ethnic groups on } \\
\text { concerns, } \\
\text { knowledge and } \\
\text { beliefs about AD } \\
\text { in adults over } 50 \\
\text { years old of a } \\
\text { sample of } \\
\text { residents of the } \\
\text { US. }\end{array}$ \\
\hline MEDLINE & $\begin{array}{l}\text { Social workers' } \\
\text { and nurses' } \\
\text { illness } \\
\text { representations } \\
\text { about Alzheimer } \\
\text { disease: an } \\
\text { exploratory } \\
\text { study }\end{array}$ & $\begin{array}{l}\text { Shinan-Altman } \\
\text { S; Werner P; } \\
\text { Cohen M. }\end{array}$ & $\begin{array}{l}\text { Alzheimer Dis } \\
\text { Assoc Disord; } \\
\text { 28(1): 73-8, } \\
\text { 2014 Jan-Mar }\end{array}$ & $\begin{array}{l}\text { Analyzed and } \\
\text { compared } A D \text { and } \\
\text { representations } \\
\text { of the disease } \\
\text { between the two } \\
\text { main professional } \\
\text { groups involved } \\
\text { in the care of } \\
\text { patients with } A D \text {. }\end{array}$ \\
\hline MEDLINE & $\begin{array}{l}\text { Levels and } \\
\text { correlates of } \\
\text { knowledge } \\
\text { about } \\
\text { Alzheimer's } \\
\text { disease among } \\
\text { older Chinese } \\
\text { Americans }\end{array}$ & $\begin{array}{l}\text { Sun F; Gao X; } \\
\text { Shen H; } \\
\text { Burnette D. }\end{array}$ & $\begin{array}{l}\text { J Cross Cult } \\
\text { Gerontol; 29(2): } \\
\text { 173-83, } 2014 \\
\text { Jun }\end{array}$ & $\begin{array}{l}\text { Analyzed the } \\
\text { knowledge of } A D \\
\text { in a sample of } \\
\text { older Chinese } \\
\text { Americans living } \\
\text { in Phoenix. }\end{array}$ \\
\hline CAPES PORTAL & $\begin{array}{l}\text { Perception of } \\
\text { Alzheimer's } \\
\text { disease in the } \\
\text { French } \\
\text { population }\end{array}$ & $\begin{array}{l}\text { Breining A ; } \\
\text { Lavallart B ; Pin } \\
\text { S ; Leon C ; } \\
\text { Moulias S ; } \\
\text { Arwidson P ; } \\
\text { Beck F ; Berr C ; } \\
\text { Verny M. }\end{array}$ & $\begin{array}{l}\text { Journal Of } \\
\text { Nutrition Health } \\
\text { \& Aging, 2014 } \\
\text { Apr, Vol.18(4), } \\
\text { pp.393-399 }\end{array}$ & $\begin{array}{l}\text { Investigated the } \\
\text { perception, } \\
\text { knowledge, } \\
\text { opinions and } \\
\text { beliefs about } A D \\
\text { in the French } \\
\text { population by } \\
\text { telephone. }\end{array}$ \\
\hline
\end{tabular}

According to the above results, one can notice the paucity of published articles on Alzheimer's disease with qualitative methodology using the Theory of Social Representations.

The integrative review determines the current knowledge about a particular subject, as it is conducted in order to identify, analyze and summarize results of studies that guide 
the same subject, contributing to a possible impact on the quality of patient care and the deepening of knowledge. ${ }^{9}$ It is highlighted that the impact of the use of integrative review occurs not only in developing policies, protocols and procedures, but also in the critical and subjective thought of the object in question. ${ }^{9-10}$

In all the analyzed productions, it is clear the contribution of studies regarding Alzheimer's disease. Matioli et al found that the higher the level of education, being females aged between 60-70 years old, the higher the knowledge about AD. ${ }^{11}$ From this, it is conceived that the prevention of late diagnosis of dementia is equivalent to acting on health promotion, especially aimed at people over 70 years old, male and less educated.

Thus, it is considered that there is room and encouragement so that other researchers invest in this perspective, using other better developed research approaches and with broader knowledge, as the social representations so that one can take from a field research more tangible conclusions, as well to enable theoretical contribution in the development of broader public health policies to care for the elderly.

Study by Connell et al identified predictors of personal fear of developing AD in $60 \%$ of the sample. This attitude was strongly related to age, becoming prevalent among the elderly. Being a caregiver or knowing someone with the disease was also strongly associated with fear among people aged between 18 and 34 years old. The results of this research guide and encourage the development of education and prevention programs focused on different age groups and $A D$ caregivers. ${ }^{6,12}$

It was found in the studies some gaps relating to methodologies, such as: questionnaire responses by telephone, leaving room for various interpretations, since a present interview can show interviewees' gestures and reactions, which confirms the interpretation of the data. Samples are relevant; questionnaires used are validated by researchers. ${ }^{12-3-4}$ All studies compared results with other authors convincingly, stimulating further research and assessments. However, there was a gap of further study in knowledge that shows the individual's relations with the world and guide their conduct and behavior in the social environment such as those using the theory of social representations.

The only study that used the speech content analysis obtained two categories: lack of knowledge and spirituality. It concluded that the fear of contracting the disease prevails and that spirituality and practice of exercises can prevent AD. ${ }^{15}$ But it failed in not detailing how the research was conducted; the methodology is not fully described, results are incomplete and the conclusion repeats findings of the results and does not fulfill the criterion of objectives achieved. The references do not meet the scope of the theme. Thus, it emphasizes the need for investment in general in research investigating the perception of Alzheimer's disease in the context of the elderly in order to have scientific basis in the development of policies and actions in this population to improve their quality of life. ${ }^{16}$

It has been shown by some authors that the prevalent culture in older African Americans can influence their perceptions and knowledge of the risk of Alzheimer's disease. Through the application of adapted risk perception scales, cultural characteristics scale and Alzheimer's disease knowledge scale, they have verified, after statistical analysis, that the perception of having little control over risks to health, since God's will influences in determining the development of Alzheimer's disease, in addition to the low knowledge about 
the disease. Authors have assumed that such diversity can contribute to differences in the detection and treatment of Alzheimer's disease in this population. ${ }^{17}$ There was no qualitative data evaluation. To assess risk perception, research questions on risk perception for diabetes were adapted to apply for Alzheimer's disease, leaving a questionable gap for methodology regarding the validation of this adaptation.

Ayalon assessed the ethnic group differences on the concerns, knowledge and beliefs about Alzheimer's disease in three ethnic groups of adults over 50 years old and their spouses of any age (whites, hispanics and blacks), and included sociodemographic variables. In this study, a total of 1252 participants answered a questionnaire, of which 654 were face to face with the interviewer and the others by telephone. Few differences were found between the groups, which indicates that education campaigns can be broadly consistent across all ethnic groups. $^{18}$

A study that analyzed and compared Alzheimer's disease and representations of the disease between the two main professional groups involved in the care of Alzheimer's patients, nurses and social workers also used an objective instrument with true or false answers to assess the knowledge of this disease and an adaptation of a reviewed questionnaire of disease representation replacing any disease by Alzheimer's disease. ${ }^{19}$ Although this study did not refer to the perception of the elderly and it is a recent survey using adapted questionnaires to evaluate perception, it points to a field of study to be assessed on the basis of Social Representations. ${ }^{16}$

Knowledge of Alzheimer's disease was studied in a sample of older Chinese Americans living in Phoenix, a metropolitan area in the United States. The survey data were collected from 385 Chinese Americans aged 55 or older, recruited from various establishments, such as elderly homes, elderly clubs, senior centers and church groups. Participants responded to a knowledge scale on Alzheimer's disease with 24 items true/false. The multivariate regression analysis found that participants who had more traditional Chinese cultural beliefs on Alzheimer's disease tend to have less knowledge about it. Women had more knowledge of the disease than men, when educational differences were controlled. This analysis indicates that educational programs about Alzheimer's disease should include, for example, risk factors, symptoms and care on which older Chinese Americans tend to have less knowledge. It shows that information about the disease must be disseminated through appropriate means to attract older Chinese Americans more effectively, addressing the prejudices of cultural beliefs of seniors about Alzheimer's disease and incorporated into educational programs of the disease. ${ }^{20}$ This study did not address perceptions nor social representations, confirming the need for further studies in the subject in order to provide knowledge of reality and context for realization of effective and targeted public policies, indicating the importance of studies on Alzheimer's disease and Social Representations.

A study that investigated the perception, knowledge, opinions and beliefs about Alzheimer's disease in the French population to improve care had a cross-sectional design described by telephone in 2008. The 2013 respondents answered a questionnaire with a series of statements about attitude on health in general and Alzheimer's disease. The results showed that $93 \%$ believed that the disease is devastating for the family. This feeling prevailed in people over 75 years old and who knew someone with AD. 95\% thought that the difficulties to 
manage administrative documents and to find the way back home suggest early onset Alzheimer's disease; 91\% would like to know the diagnosis if they had Alzheimer's disease and $38 \%$ reported knowing or having known at least one patient within their social circle. This study concluded that the overall representation of Alzheimer's disease has been changing in a positive way and, despite being perceived as a calamity, people are confident that solutions will be found in future. ${ }^{21}$ It was noted that the study did not prioritize respondents' lines and, therefore, requests, from its findings, studies that include a broader view. Authors continue stating that the general population has a reasonable knowledge of Alzheimer's disease, but is still unable to recognize the early stages. In addition to this, respondents think that care for patients with Alzheimer's disease could be better, but they trust the French government to improve it.

\section{CONCLUSION}

In Brazil, the number of elderly people with dementia has grown rapidly, but there is lack of qualitative data on this theme. The achievement of the research objective lies in the fact that there is in databases a vast list of indexed articles on Alzheimer's disease in its various aspects, but when one needs an analysis on the theoretical framework of Social Representations, ${ }^{14,16}$ of perceptions, knowledge and attitudes of the aging population, as well as policy suggestions, actions and health interventions measures, the relevant literature still has gaps to be filled.

There is need for investment for the development of research to remedy the lack of scientific arsenal, based on validated research techniques in order to investigate the behavior of elderly patients in face of Alzheimer's disease and how they guide their conduct and so that we can suggest interventions and health policies, with the main purpose to improve the quality of life for seniors.

\section{REFERENCES}

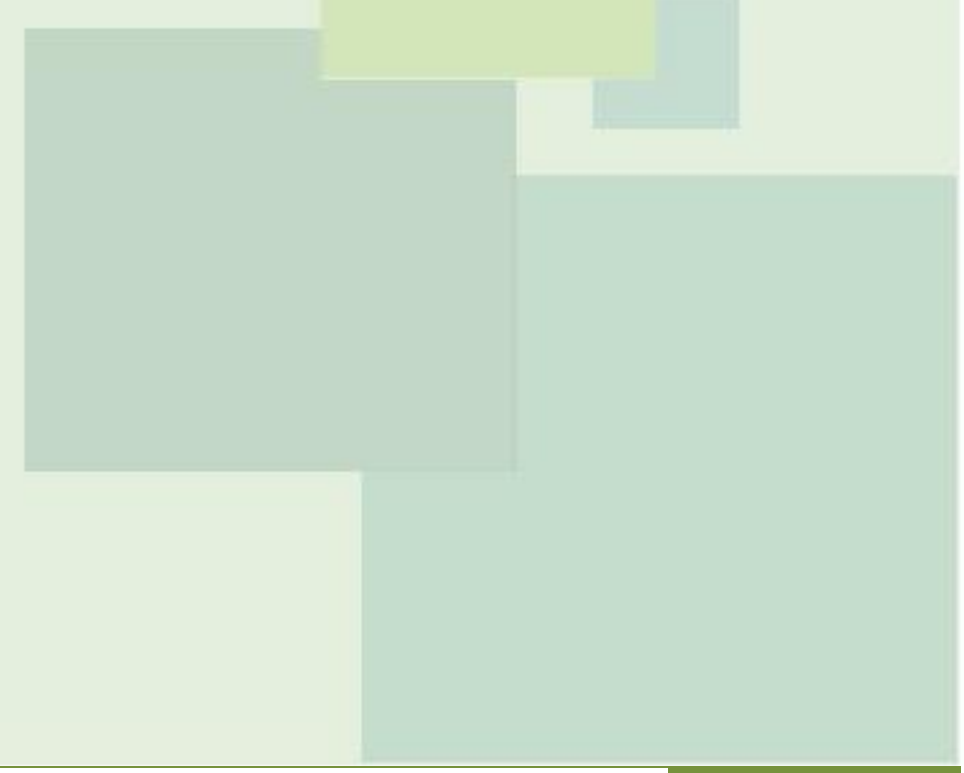


1. WHO (World Health Organization). Envelhecimento ativo: uma política de saúde tradução Suzana Gontijo. Brasília: Organização Pan-Americana da Saúde; 2005.

2. DSM-V. Manual diagnóstico e estatístico de transtornos mentais. $5^{a}$ ed. Porto Alegre: Artmed; 2014.

3. Kalaria RJ, Maestre GE, Arizaga R, Friedland RP, Galasko D, Hall K, et al. Alzheimer's

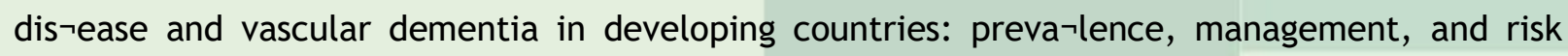
factors. Lancet Neurol. 2008;7(9):812-26.

4. Solomon A, Mangialasche F, Richard E, Andrieu S, Bennett DA, Breteler M, et al. Advances in the prevention of Alzheimer's disease and dementia. J Intern Med. 2014;275(3):229-50.

5. Bradford A, Kunik ME, Schulz P, Williams SP, Singh H. Missed and delayed diagnosis of dementia in primary care: prevalence and contributing factors. Alzheimer Dis Assoc Disord. 2009;23(4):306-14.

6. Connell CM, Roberts S, McLaughlin SJ, Akinleye D. Racial Differences in knowledge and beliefs about Alzheimer disease. Alzheimer Dis Assoc Disord. 2009;23(2):110-16.

7. MOSCOVICI, S. A representação social da psicanálise. Rio de Janeiro: Zahar editores; 1978. 8. Mendes KDS, Silveira RCCP, Galvão CM. Revisão integrativa: método de pesquisa para a incorporação de evidências na saúde e na enfermagem. Texto contexto - enferm. [online]. 2008 [citado março 2012]; 17(4):758-764. Disponível em: http: / / www.scielo.br/scielo.php?script=sci_arttext\&pid=S0104-07072008000400018

9. Souza MT, Silva MD, Carvalho R. Revisão Integrativa: o que é e como fazer. Einsten. [online]. 2010 [citado setembro 2013]; 8(1 Pt 1):102-6. Disponível em: http:// www.astresmetodologias.com/material/O_que_e_RIL.pdf

10. Stetler CB, Morsi D, Rucki S, Broughton S, Corrigan B, Fitzgerald J, et al. Utilizationfocused integrative reviews in a nursing service. Appl Nurs Res. 1998;11(4):195-206.

11. Matioli MNPS, Etzel A, Prats JAGG, Medeiros WFO, Monteiro TR, Soares AM. Worries about memory loss and knowledge on Alzheimers disease in community-dwelling elderly from Brazil. Dement Neuropsychol. 2011;5(2):108-13.

12. Cantegreil-Kallen I, Pin S. Fear of Alzheimer's disease in the French population: impact of age and proximity to the disease. International Psychogeriatrics. 2012;24(1):108-116.

13. Corner L, Bond J. Being at risk of dementia: fears and anxiety of older adults. Journal of Aging Studies. 2004;18: 143-155.

14. Bardin, L. Análise de conteúdo. Trad. Luís Antero Reto e Augusto Pinheiro. Lisboa: Edições 70; 2011.

15. Oliveira AA, Albuquerque FMD, Fonseca GA, Almeida VLV. A demência de Alzheimer e os idosos: investigação sobre conhecimento, prevenção e percepção. FIEP BULLETIN - Volume 82 Special Edition - ARTICLE I - 2012. Acessado em 21/03/2015. Disponível em: http://fiepbulletin.net/index.php/fiepbulletin/article/view/2416/4511.

16. Moreira ASP, Jesuino JC. Representações Sociais: Teoria e Prática. João Pessoa: Universitária /UFPB; 2003.

17. Rovner BW; Casten RJ; Harris LF. Cultural diversity and views on Alzheimer disease in older African Americans. Alzheimer Dis Assoc Disord. 2013;27(2):133-137.

18. Ayalon L. Re-examining ethnic differences in concerns, knowledge, and beliefs about Alzheimer's disease: results from a national sample. Int J Geriatr Psychiatry. 2013;28(12):128895. 
19. Shinan-Altman S; Werner P; Cohen M. Social workers' and nurses' illness representations about Alzheimer disease: an exploratory study. Alzheimer Dis Assoc Disord. 2014;28(1):73-8. 20. Sun F; Gao X; Shen H; Burnette D. Level s and correlates of knowledge about Alzheimer's disease among older Chinese Americans. J Cross Cult Gerontol. 2014;29(2):173-83.

21. Breining A, Lavallart B, Pin S, Leon C, Moulias S, Arwidson P, et al. Perception of Alzheimer's disease in the French population. J Nutr Health Aging. 2014;18(4):393-99.

Received on: 28/05/2015 Required for review: No Approved on: 12/08/2015 Published on: 07/01/2016
Contact of the corresponding author: Ronaldo Bezerra de Queiroz

Av. Umbuzeiro 1237, Ap 402, Edf. Louvre, Manaíra, João Pessoa - PB Fone (83) 9 9981-3207 / 9 8886-3172. E-mail: qronaldo@hotmail.com 